\title{
PENINGKATAN KETERAMPILAN BERDISKUSI MELALUI STRATEGI ELVES (EXCITE, LISTEN, VISUALIZE, EXTEND, AND SAVOR) PADA SISWA KELAS VIII F SMP NEGERI 1 SELAT KUALA KAPUAS
}

\author{
Melania Sugiyarti \\ melania meli@gmail.com \\ SMP NEGERI I SELAT KUALA KAPUAS
}

\begin{abstract}
This research aims to improve the skills of discussion grade VIII F SMP Negeri 1 Strait by using strategies of ELVES (Excite, Listen, Visualize, Extend, and Savor). Through a strategy of ELVES (Excite, Listen, Visualize, Extend, and Savor), an increase can be seen in the process as well as in products.

This type of research this is a class action research (PTK). The research was carried out in junior high Country with the subject Straits 1 is grade VIII F, consisting of 35 students. Collaboration between researchers with English subjects in this study for three sikus. Techniques used include data collection, observation, interview, a skills test, and discuss the Notes field. Research instrument used is a sheet of observation, interview guidelines, notes field, and discussion skills assessment sheets students.

The results showed that, the use of strategies of ELVES (Excite, Listen, Visualize, Extend, and Savor) can improve learning skills in discussing grade VIII F SMP Negeri 1 Strait. The increase shown from the quality of the learning process that reflected the spirit of learning, students ' attention towards learning, active students, the learning process, and the opportunity to speak. The increase in products can be seen from the average score of pratindakan discussion skills until the cycle III. On pratindakan, score an average of 8.09 earned class, then increased to 14.03 on cycle I and cycle II 18.77. The last increase occurred in cycle III i.e. be 21.52. An increase in the average score of the cycle I to III of 7.49 cycle, while the average score of the class from pratindakan to cycle III of 13.43 .
\end{abstract}

Key words: skill discussions through a strategy of ELVES (Excite, Listen, Visualize, Extend, and savorr.

PENDAHULUAN
Berbicara merupakan kebutuhan
sosial setiap insan di dunia.
Dalam setiap kesempatan,
berbicara menjadi alat

komunikasi tatap muka yang sangat vital. Mungkin tepat rasanya anggapan sebagian besar orang, bahwa kemampuan berbicara seseorang turut menentukan kesuksesan karir 
orang tersebut. Tidak terkecuali dalam kegiatan belajar mengajar di kelas. Terlebih lagi dalam pembelajaran Bahasa Indonesia terdapat empat aspek kebahasan yang salah satunya adalah berbicara.

Siswa diharapkan untuk lebih aktif dalam mengikuti pembelajaran di kelas. Siswa diharapkan tidak lagi segan untuk berbicara mengeluarkan ide- idenya. Banyak cara yang bisa ditempuh dalam kegiatan berbicara untuk melatih kemampuan berbicara seorang siswa yang meliputi, pidato, diskusi, ceramah, dan masih banyak lagi yang lainnya.

$$
\text { Diskusi merupakan }
$$
respon yang diharapkan setelah melalui tahap mengidentifikasi masalah, melalui kegiatan mendengar, membaca, merumuskan pemecahan masalah, dan selanjutnya menyampaikan ide serta gagasan untuk memecahkan masalah. Keterampilan berdiskusi tidak hanya diperoleh begitu saja, tetapi harus dipelajari dan dilatih. Keterampilan berdiskusi yang baik dapat dimiliki dengan mengasah serta melatih seluruh potensi yang ada.

Oleh karena itu, penggunaan metode pengajaran sangat berpengaruh terhadap keberhasilan proses belajar mengajar. Salah satu cara untuk meningkatkan kemampuan berdiskusi siswa adalah dengan menerapkan strategi ELVES (Excite, Listen, Visualize, Extend and Savor). Sebuah strategi yang dirancang oleh Katherine D. Wiesendanger dalam bukunya yang berjudul Strategies for Literacy Education. Wiesendanger (2001: 57-58) memaparkan bahwa, strategi ini memiliki tahapan yang berupa menggugah, mendengar, melihat, menikmati, dan menyampaikan. Strategi ini memberikan kerangka bagaimana menjalankan sebuah diskusi kelas agar dapat menghasilkan pembelajaran diskusi yang berkualitas. 


\section{METODE PENELITIAN}

Metode dalam penelitian pengajaran keterampilan diskusi dapat mengevaluasi dan dapat informasi dan adanya asosiasi antara katerampilan berdiskusi yang lain. Penelitian dilakukan guna mencapai perbaikan praktik secara berkelanjutan. Tindakan tersebut diberikan oleh guru atau dengan arahan guru yang dilakukan oleh pesirta didik. Jenis penelitian ini dipilih karena peneliti ingin mengetahui peningkatan keterampilan diskusi kelompok secara proses dan hasil pembelajaran .

Objek penelitian ini adalah keterampilan berdiskusi siswa yang mencakup proses dan hasil. Objek penelitian yang berupa proses adalah pelaksanaan proses keterampilan berdiskusi

Acuan yang dijadikan pedoman penelitian ini adalah model Kemmis dan Mc. Taggart yang mencakup penyusunan rencana (plan), perlakukan (act), pengamatan (observe), dan refleksi (reflect). Adapun gambar mengenai model desain penelitian berdasarkan model Kemmis dan Mc. Taggart dalam (Madya, 2011: 59-67) sebagai berikut.

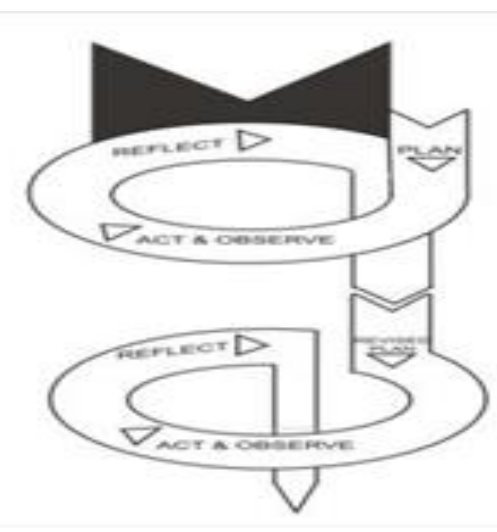

\section{Model Penelitian Tindakan}

\section{Kelas}

Instrumen penelitian yang untuk digunakan untuk mengumpulkan data dalam penelitian ini berupa tes dan nontes. Teknik ini adalah dengan menggunakan angket, tes, wawancara, catatan lapangan, dan alat rekaman gambar.

Konsep validitas dalam aplikasinya untuk penelitian tindakan kelas mengacu kepada kredibilitas dan derajat keterpercayaan dan hasil penelitian,menyatakan ada 


$$
\begin{aligned}
& \text { empat kriteria validitas, yaitu } \\
& \text { validitas hasil, validitas, proses, } \\
& \text { validitas demokratis, dan } \\
& \text { validitas dialog. } \\
& \text { Penelitian } \\
& \text { menggunakan teknik analisis } \\
& \text { deskriptif kualitatif. Analisis } \\
& \text { deskriptif kualitatif yaitu untuk } \\
& \text { mendeskripsikan keterampilan } \\
& \text { berbicara sebelum dan sesudah } \\
& \text { implementasi tindakan. } \\
& \text { Kemampuan berbicara siswa } \\
& \text { dinilai dengan pedoman } \\
& \text { penilaian yang sudah } \\
& \text { ditentukan. }
\end{aligned}
$$

Kriteria Keberhasilan Tindakan

Keberhasilan penelitian tindakan ditandai dengan adanya perubahan menuju arah perbaikan. Indikator keberhasilan terdiri atas keberhasilan proses dan keberhasilan produk.

$$
\text { Indikator keberhasilan }
$$

proses dapat dilihat dari beberapa hal.

1) Proses pembelajaran

dilaksanakan dengan menarik dan menyenangkan

2) Siswa aktif berperan serta selama proses pembelajaran berlangsung

3) Siswa menunjukkan respon antusias ketika proses pembelajaran berlangsung

4) Siswa menghasilkan ide kreatif dalam meyampaikan gagasannya

5) Siswa paham tentang pembelajaran berdiskusi dengan strategi ELVES (Excite, Listen, Visualize, Extend and Savor).

Indikator keberhasilan produk

$$
\begin{array}{lrr} 
& \text { Keberhasilan } & \text { secara } \\
\text { produk } & \text { dapat dilihat } \\
\text { berdasarkan } & \text { peningkatan } \\
\text { jumlah skor rata-rata yang }
\end{array}
$$
diperoleh pada setiap siklus. Tindakan ini dikatakan berhasil apabila 75\% siswa mendapatkan skor lebih dari atau sama dengan 19 dari skor maksimal 25.

\section{HASIL PENELITIAN}

\section{DAN PEMBAHASAN}

\section{Hasil Penelitian Tes Prasiklus}

Penelitian ini menggunakan strategi ELVES (excite, listen, visualize, extend, and 
savor) dalam pembelajaran diskusi. Pada bab ini akan disampaikan hasil penelitian yang sesuai dengan rumusan masalah yang diajukan. Hasil penelitian dideskripsikan secara rinci dimulai dari perencanaan, pelaksanaan tindakan, pengamatan, dan refleksi. Dalam hasil penelitian ini akan disajikan hasil dari kemampuan berbicara siswa dari pratindakan sampai akhir siklus III. Hasil yang diperoleh dari penelitian tindakan kelas akan diungkapkan di bawah ini.

Tabel 1.

Skor Awal Keterampilan

\section{Berdiskusi}

tiap Aspek pada tes Prasiklus memecahkan masalah. Pada aspek ini hal yang diperhatikan adalah bagaimana kemampuan siswa dalam bekerja sama, kemampuan siswa dalam menghargai pendapat siswa lain, dan kemampuan siswa dalam berperan untuk menyelesaikan perbedaan pendapat serta kemampuan menerima hasil-hasil diskusi yang telah disepakati. Pada tahap pratindakan diperoleh hasil skor rata-rata kelas pada aspek sikap kooperatif di antara para anggota sebesar 1,62.

Hasil dari masingmasing aspek dapat dilihat pada diagram berikut.

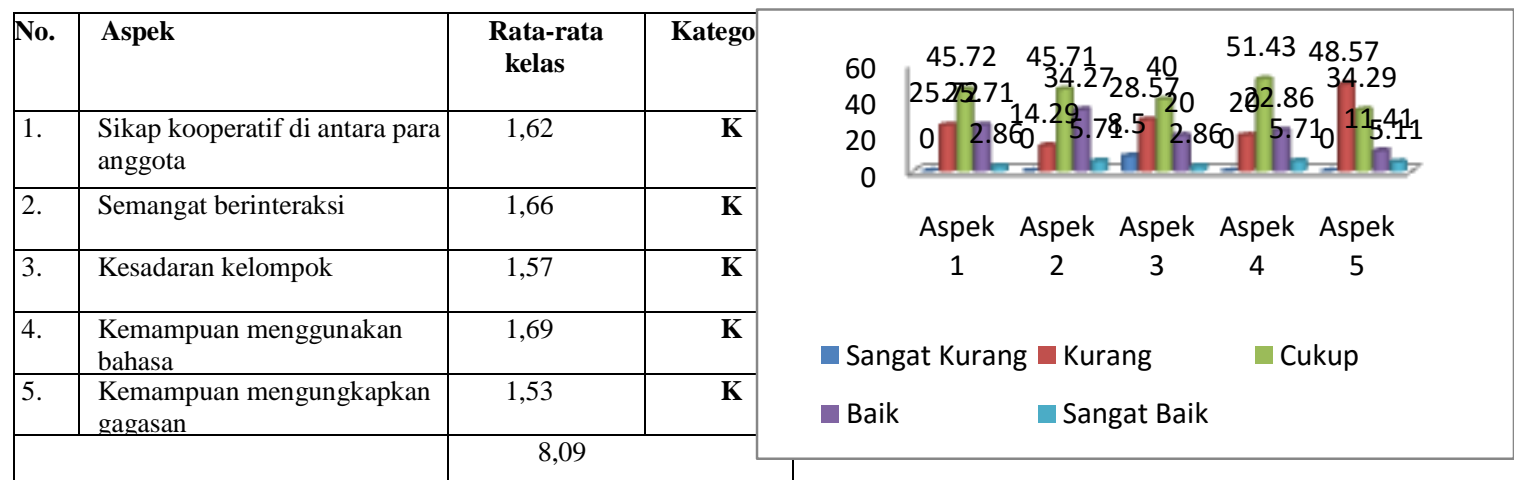

Sumber data diolah tahun 2017

$$
\text { Pada tabal } 1 \text { aspek }
$$

sikap kooperatif di antara para anggota ini berkaitan dengan kekompakan siswa dalam
Diagram I:

Histogram Hasil Pengamatan Pembelajaran Diskusi 
pada Tahap Pratindakan (dalam \%)

Keterangan:

Aspek 1 : Semangat belajar

Aspek 2 : Perhatian terhadap pembelajaran

Aspek 3 : Keaktifan

Aspek 4 : Proses

belajar

Aspek 5 :

Kesempatan berbicara

Berdasarkan diagram 1

dapat disimpulkan bahwa setiap

aspek dalam pengamatan proses

memiliki hasil yang berbeda-

beda. Dua aspek mendapat nilai

cukup yaitu aspek semangat

belajar dan perhatian. Pada

aspek semangat belajar

mendapat skor $46,87 \%$

sedangkan aspek perhatian

terhadap pembelajaran sebesar

46,88\%. Dua aspek berikutnya

masuk dalam kategori sangat

kurang, yaitu aspek keaktifan

sebesar 56,25\% dan aspek

kesempatan berbicara sebesar

$46,88 \%$. Sedangkan satu aspek

yaitu semangat belajar masuk

dalam kategori kurang, sebesar

$40,63 \%$ siswa.

\section{Hasil Penilaian}

Tes Siklus 1

Penelitian tindakan

kelas dengan judul

Peningkatan Keterampilan

Berdiskusi melalui Strategi

ELVES (Excite, Listen,

Visualize, Extend, and Savor)

pada Siswa Kelas VIII SMP N

1 Selat dilaksanakan dalam

tiga siklus. Perbedaan dari

siklus pertama hingga siklus ketiga.

Pengamatan dilakukan

oleh peneliti bersama

kolaborator dengan

berpedoman pada lembar

penilaian diskusi.

Berdasarkan skor penilaian

diskusi pada siklus I ini

dapat dilihat peningkatan

keterampilan berdiskusi.

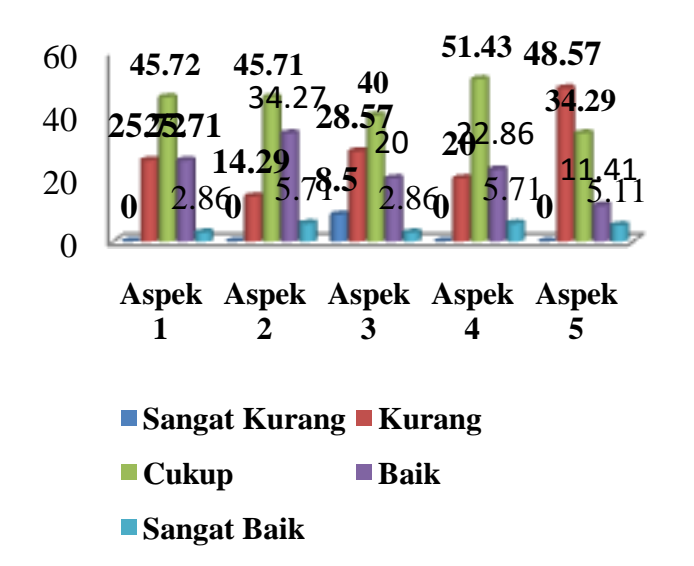




\section{Diagram II:}

\section{Histogram Hasil}

\section{Pengamatan}

Pembelajaran Diskusi pada

\section{Siklus I (dalam \%)}

\section{Berdasarkan histogram}

tersebut dapat diketahui

bahwa empat aspek

keterampilan siswa dalam

berdiskusi termasuk dalam

kategori cukup baik. Empat

aspek tersebut adalah aspek semangat belajar yaitu sebesar $45,72 \%$, aspek perhatian

terhadap pembelajaran sebesar $\quad 45,71 \%$, aspek keaktifan sebesar $40 \%$, dan aspek proses belajar yaitu sebesar 51,43\%. Satu aspek yaitu aspek kesempatan berbicara menunjukkan bahwa termasuk dalam kategori kurang, yaitu sebesar $48,57 \%$.

Tabel 2:

Peningkatan Skor Keterampilan Diskusi dari

Pratindakan ke Siklus I

\begin{tabular}{|c|l|c|c|l|l|}
\hline No & \multicolumn{1}{|c|}{ Aspek } & $\begin{array}{c}\text { Rata-rata } \\
\text { Pratindakan }\end{array}$ & $\begin{array}{c}\text { Rata-rata } \\
\text { Siklus I }\end{array}$ & Peningkatan & Kategori \\
\hline 1. & Sikap kooperatif di antara & 1,62 & 2,97 & 1,35 & $\mathrm{C}$ \\
\hline 2. & Semangat berinteraksi & 1,66 & 2,77 & 1,11 & $\mathrm{C}$ \\
\hline 3. & Kesadaran kelompok & 1,59 & 2,89 & 1,3 & $\mathrm{C}$ \\
\hline 4. & $\begin{array}{l}\text { Kemampuan menggunakan } \\
\text { bonon }\end{array}$ & 1,69 & 2,88 & 1,11 & $\mathrm{C}$ \\
\hline 5. & Kemampuan & 1,53 & 2,6 & 1,07 & $\mathrm{C}$ \\
\hline & Jumlah & 8,09 & 14,03 & 5,94 & \\
\hline
\end{tabular}

Keterangan:

SB : Sangat baik dengan nilai rata-rata kelas $\leq 5$

B $\quad$ : Baik dengan nilai rata-rata kelas $\leq 4$

C : Cukup dengan nilai rata-rata kelas $\leq 3$

$\mathrm{K} \quad$ : Kurang dengan nilai rata-rata kelas $\leq 2$

SK : Sangat kurang dengan nilai rata-rata kelas $\leq 1$

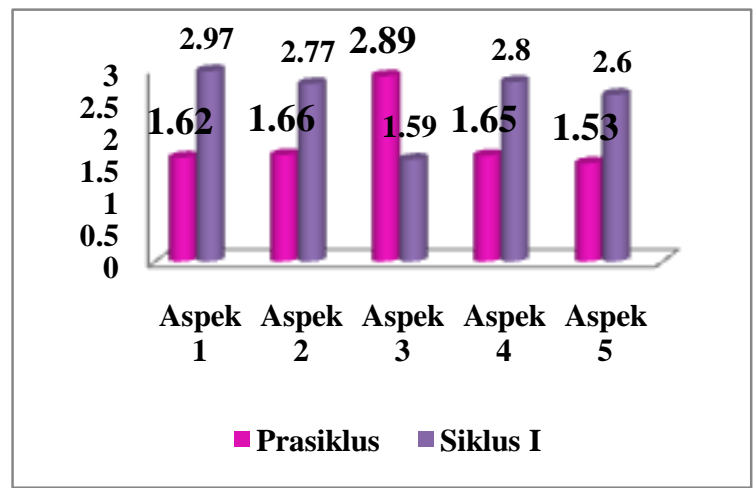

Diagram II:

Histogram Peningkatan Skor

Keterampilan

Berdiskusi dari Pratindakan ke Siklus 1

Berdasarkan tabel 2 dan diagram II tersebut dapat diketahui bahwa skor rata-rata 
siswa tiap-tiap aspek untuk keterampilan berdiskusi setelah dikenai tindakan terdapat peningkatan. Peningkatan terbesar terdapat pada aspek sikap kooperatif di antara para anggota yang meningkat sebesar 1,35, dilanjutkan aspek kesadaran kelompok yang mengalami peningkatan sebesar 1,3. Peningkatan dengan jumlah yang sama dialami oleh aspek semangat berinteraksi dan kemampuan menggunakan menggunakan bahasa, yaitu sebesar 1,11. Peningkatan dengan jumlah rata-rata terkecil dialami oleh aspek kemampuan mengungkapkan gagasan yaitu sebesar 1,07. Berikut ini akan dideskripsikan mengenai peningkatan pada setiap aspek.

\section{Hasil Penilaian Tes}

Siklus II

Perencanaan penelitian tindakan kelas pada siklus II ini bertujuan untuk meningkatkan aspek-aspek yang belum tercapai pada siklus I.
Adapun aspek-aspek yang masih perlu ditingkatkan, yaitu pemahaman siswa yang masih kurang terhadap prosedur pelaksanaan strategi ELVES (Excite, Listen, Visualize, Extend, and Savor), semangat siswa masih kurang maksimal, pemerataan kesempatan berbicara, sikap kooperatif dalam kelompok, interaksi siswa di dalam kelompoknya, kemampuan menggunakan bahasa, dan keberanian siswa untuk berbicara.

Pelaksanaan tindakan pada siklus II ini diharapkan dapat meningkatkan aspek - aspek yang masih kurang maksimal pada siklus I. Pelaksanaan tindakan siklus II ini dilakukan sebanyak dua kali pertemuan. Secara keseluruhan proses pembelajaran diskusi mengalami peningkatan pada tiap aspeknya. Jika pada siklus I hasil pengamatan menunjukkan bahwa keterampilan siswa berdiskusi masuk kategori cukup, pada siklus II ini rata-rata seua semua aspek masuk dalam kategori 


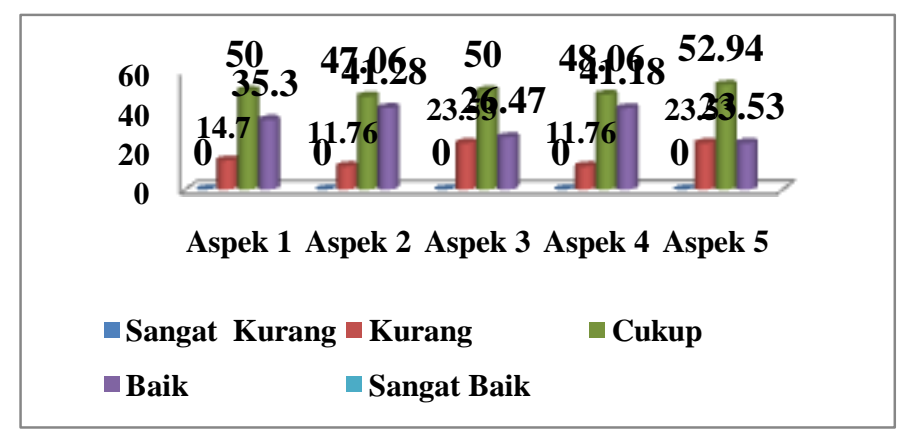

Diagram III :

Histogram Hasil Pengamatan

Pembelajaran

Diskusi pada Siklus II (dalam

$\%)$

Keterangan:

Aspek 1 : Semangat

belajar

Aspek 2 : Perhatian

terhadap pembelajaran

Aspek 3 : Keaktifan

Aspek 4 : Proses belajar
Aspek 5 : Kesempatan

berbicara

Secara produk,

keberhasilan tindakan dapat

dilihat dari nilai keterampilan diskusi siswa pada siklus II. Kegiatan diskusi yang dilakukan pada siklus II ini mengalami peningkatan dari tindakan sebelumnya. Siswa mengalami peningkatan dalam kegiatan diskusi pada tiap-tiap aspeknya. Berikut ini tabel dan diagram peningkatan keterampilan diskusi dari kegiatan siklus I ke siklus II.

Tabel 4: Peningkatan Skor Keterampilan Berdiskusi dari Siklus I ke Siklus II

\begin{tabular}{|c|c|c|c|c|c|}
\hline No & Aspek & $\begin{array}{l}\text { Rata-rata } \\
\text { siklus I }\end{array}$ & $\begin{array}{l}\text { Rata-rata } \\
\text { Siklus II }\end{array}$ & Peningkatan & Kategori \\
\hline 1. & $\begin{array}{l}\text { Sikap kooperatif } \\
\text { di antara para anggota }\end{array}$ & 2,97 & 4,0 & 1,12 & SB \\
\hline 2. & Semangat berinteraksi & 2,77 & 3,59 & 0,82 & B \\
\hline 3. & Kesadaran kelompok & 2,89 & 3,85 & 0,96 & B \\
\hline 4. & $\begin{array}{l}\text { Kemampuan } \\
\text { menggunakan bahasa }\end{array}$ & 2,8 & 3,74 & 0,94 & B \\
\hline 5. & $\begin{array}{l}\text { Kemampuan } \\
\text { mengungkapkan }\end{array}$ & 2,6 & 3,5 & 0,9 & B \\
\hline \multicolumn{2}{|r|}{ Jumlah } & 14,03 & 18,77 & 4,74 & \\
\hline
\end{tabular}

Keterangan:

$\mathrm{SB} \quad$ : Sangat baik dengan nilai rata-rata kelas $\leq 5$

B : Baik dengan nilai rata-rata kelas $\leq 4$

C : Cukup dengan nilai rata-rata kelas $\leq 3$

$\mathrm{K}$ : Kurang dengan nilai rata-rata kelas $\leq 2$

SK : Sangat kurang dengan nilai rata-rata kelas $\leq 1$ 
pada siklus I adalah sebesar

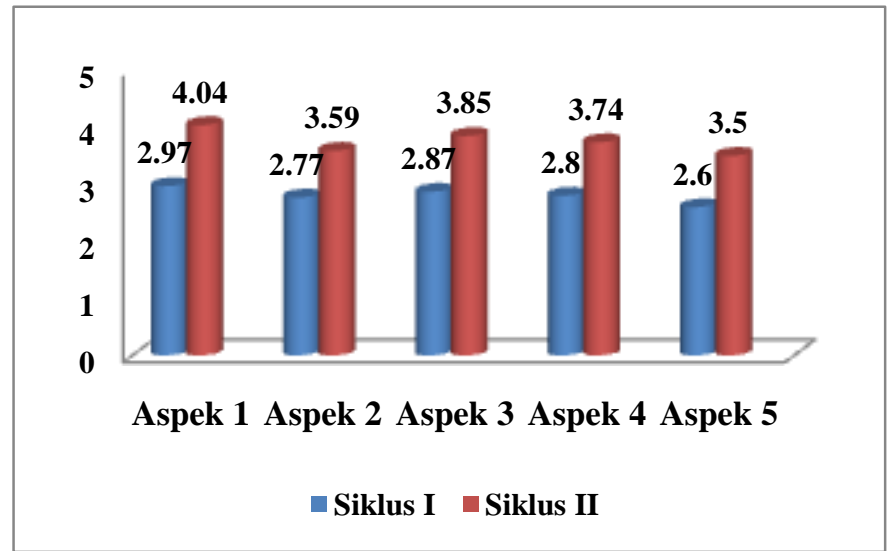
14,03, sedangkan pada siklus II sebesar 18,77. Peningkatan untuk setiap aspeknya adalah sebagai berikut, aspek sikap kooperatif di antara anggota meningkat sebesar 1,12 dengan skor rata-rata kelas yang diperoleh pada siklus I adalah

Diagram IV: Diagram Batang Peningkatan Skor

Keterampilan Berdiskusi dari Siklus I ke Siklus II

Berdasarkan tabel 4 dan diagram IV di atas, keterampilan yang dimiliki oleh siswa meningkat setelah dikenai tindakan pada siklus II. Peningkaan nilai rata-rata kelas yang tertinggi adalah pada aspek kemampuan mengungkapkan gagasan, sedangkan aspek yang mengalami peningkatan nilai rata-rata terkeci adalah kemampuan menggunakan bahasa.

- Peningkatan dapat dilihat dari skor rata-rata kelas pada siklus I ke siklus II. Skor rata-rata untuk semua aspek
2,97 dan skor rata-rata kelas pada siklus II sebesar 4,09. Aspek semangat berinteraksi meningkat sebesar 0,82 dengan skor rata-rata pada siklus I sebesar 2,77 dan skor rata-rata pada siklus II sebesar 3,59. Aspek kesadaran kelompok meningkat sebesar 0,96 yang meningkat dari 2,89 pada siklus I menjadi 3,85 pada siklus II. Aspek kemampuan menggunakan bahasa meningkat dari 2,8 pada siklus I menjadi 3,74 pada siklus II. Peningkatayang terjadi adalah sebesar 0,94. Aspek kemampuan mengungkapkan gagasan mengalami peningkatan sebesar 0,9 dengan skor rata-rata yang diperoleh pada siklus I sebesar 
2,6 dan 3,5 pada siklus II.

\section{Hasil Penilaian Tes}

\section{Siklus III}

Penelitian tindakan

kelas pada siklus III membahas tentang upaya meningkatkan kemampuan diskusi siswa menggunakan strategi ELVES (Excite, Listen, Visualize, Extend, and Savor). Penelitian ini meliputi empat tahap yaitu tahap perencanaan siklus III, pelaksanaan tindakan siklus III, pengamatan siklus III, dan refleksi.

Tahap perencanaan dilakukan oleh peneliti bersama kolaborator terkait dengan masih adanya kendala pada siklus II. Oleh karena itu, peneliti bersama kolaborator berkoordinasi untuk merencanakan tindakan pada siklus III. Pada siklus III ini, penelitian akan memfokuskan pada kemampuan siswa dalam mengungkapkan gagasan.

Hasil pengamatan secara proses dapat dilihat dari histogram di bawah ini

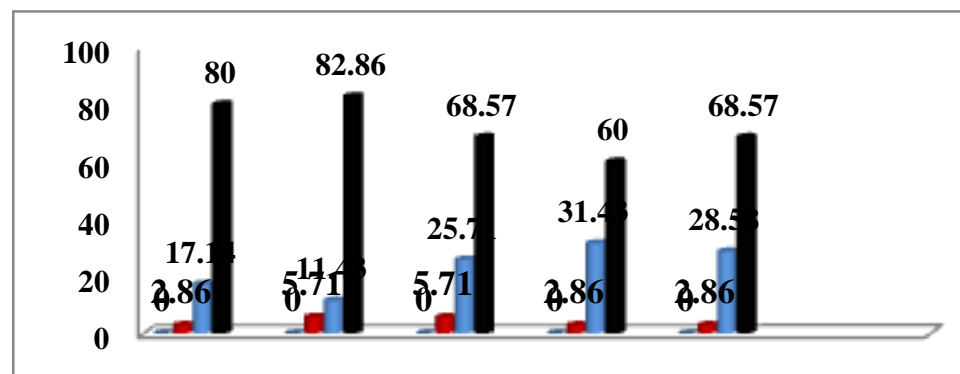

Aspek 1 Aspek 2 Aspek 3 Aspek 4 Aspek 5 Sangat Kurang Kurang Cukup Baik Sangat Baik

Diagram V:

Histogram Hasil Pengamatan Pembelajaran

Diskusi pada Siklus III (dalam \%)

\section{Keterangan:}

Aspek 1: Semangat belajar Aspek 2 : Perhatian terhadap pembelajaran

Aspek 3 : Keaktifan

Aspek 4: Proses belajar

Aspek 5: Kesempatan

berbicara

Aspek semangat siswa masuk dalam kategori sangat baik yaitu sebesar $80 \%$. Begitu juga dengan empat aspek lain yang masuk kategori sangat baik. Aspek perhatian siswa sebesar $\quad 82,86 \%$, aspek keaktifan siswa sebesar $68,57 \%$, aspek pembelajaran mencapai $60 \%$ dan aspek kesempatan berbicara mencapai $68,57 \%$. 
Keberhasilan

tindakan secara produk dapat dilihat dari nilai keterampilan diskusi yang diperoleh oleh siswa. Nilai keterampilan berdiskusi kelas pada siklus III ini mengalami peningkatan. Berikut ini tabel dan diagram peningkatan keterampilan diskusi dari kegiatan siklus II ke kegiatan siklus III.

\section{PEMBAHASAN}

Pada siklus III ini sikap kooperatif diantara para anggota mengalami peningkatan jika dibandingkan dari siklus II. Peningkatan yang terjadi adalah sebesar 0,45. Aspek ini pada siklus II memperoleh nilai rata-rata sebesar 4,09 dan berubah menjadi 4,54 pada siklus 4,54. Dengan nilai rata-rata tersebut aspek sikap kooperatif di antara para anggota masuk dalam kategori sangat baik. Berdasarkan pengamatan yang dilakukan oleh peneliti pada siklus III ini, aspek sikap kooperatif di antara para anggota mengalami banyak peningkatan.

Aspek semangat berinteraksi yang pada siklus II masuk kategori baik, pada siklus III meningkat menjadi kategori sangat baik. Skor rata-rata kelas yang diperoleh pada siklus II sebesar 3,59, mengalami peningkatan sebesar 0,67 pada siklus III menjadi 4,26. Berdasarkan pengamatan yang dilakukan oleh peneliti, interaksi siswa saat diskusi berlangsung mengalami peningkatan.

$$
\text { Aspek kesadaran }
$$
kelompok meningkat dari skor rata-rata kelas yang diperoleh pada siklus II sebesar 3,85 meningkat menjadi 4,49 pada siklus III. Peningkatan yang terjadi dari siklus II ke siklus III adalah sebesar 0,64. Aspek kesadaran kelompok pada 
siklus III ini masuk ke dalam kategori sangat baik. Pada siklus III ini, siswa sudah semakin peduli dengan kelompoknya. Siswa terlihat lebih merasa bertanggung jawab.

Aspek
menggunakan bahasa pada
siklus III mengalami
peningkatan sebesar 0,4 . Skor
ini diperoleh dari skor rata-rata
siklus II sebesar 3,74 menjadi
4,14 pada siklus III.

Kemampuan

mengungkapkan gagasan pada siklus III memperoleh skor ratarata sebesar 4,29. Skor ini mengalami peningkatan sebesar 0,79 karena sebelumnya pada siklus II aspek kemampuan mengungkapkan gagasan memperoleh skor rata-rata sebesar 4,29.

Secara produk, keberhasilan strategi ELVES (Excite, Listen, Visualize, Extend and Savor) dalam upaya meningkatkan keterampilan berdiskusi dapat dilihat dari rata-rata tes keterampilan diskusi pada siklus III. Sikap kooperatif di antara para anggota meningkat 0,45 dibandingkan pada siklus II. Pada siklus II, skor rata-rata kelas dari sikap kooperatif di antara para anggota adalah sebesar 4,09 yang meningkat menjadi 4,54 pada siklus III. Aspek semangat berinteraksi mengalami peningkatan sebesar 0,67 yang meningkat dari 3,59 pada siklus II menjadi 4,26 pada siklus III. Aspek kesadaran kelompok mengalami peningkatayang sebesar 0,64. Hasil ini diperoleh dari skor rata-rata kelas sebesar 3,85 pada siklus II menjadi 4,49 pada siklus III. Aspek kemampuan menggunakan bahasa yang pada siklus II memperoleh skor ratarata kelas sebesar 3,74 meningkat 0,4

pada siklus III menjadi 4,14. Kemampuan mengungkapkan gagasan meningkat dari 3,5 pada siklus II menjadi 4,29 pada siklus III. Skor tersebut 
menunjukkan bahwa aspek kemampuan mengungkapkan gagasan meningkat sebesar 0,79.

\section{KESIMPULAN}

Peningkatan proses dapat dilihat dari beberapa aspek, yaitu

(1) semangat belajar,

perhatian terhadap proses pembelajaran, (3) keaktifan, (4)

proses belajar, dan

kesempatan berbicara. Semangat belajar siswa meningkat setelah diberi tindakan dengan menggunakan strategi ELVES (Excite, Listen, Visualize, Extend and Savor). Siswa tidak lagi merasa terbebani dengan diberikannya tugas diskusi, karena siswa mengerti apa yang harus dilakukan dalam diskusi.

$$
\text { Peningkatan produk }
$$

dapat dilihat dari beberapa aspek yaitu (1) sikap kooperatif di antara para anggota, (2) semangat berinteraksi,

kesadaran kelompok,

kemampuan menggunakan

bahasa, (5) kemampuan mengungkapkan gagasan. Peningkatan secara produk dapat dilihat dari skor rata- rata kelas yang diperoleh dari tahap pratindakan hingga pada siklus III. Saat pratindakan skor ratarata yang diperoleh adalah 8,09. Skor rata-rata tersebut kemudian meningkat lagi menjadi 14,03 pada siklus I dan 18,77 pada siklus II. Peningkatan yang terakhir terjadi pada siklus III yaitu menjadi 21,52. Peningkatan skor rata-rata dari siklus I hingga siklus III adalah sebesar 7,49 , sedangkan skor rata-rata kelas dari pratindakan hingga siklus III adalah sebesar 13,43. Hasil dari tindakan yang dilakukan hingga siklus III telah memenuhi indikator keberhasilan produk.

Berdasarkan hasil penelitian keterampilan berdiskusi siswa kelas VIII F SMP Negeri 1 Selat dengan menggunakan strategi ELVES (Excite, Listen, Visualize, Extend and Savor), maka penelitian ini akan ditindaklanjuti sebagai berikut.

1. Guru Bahasa Indonesia SMP 
Negeri 1 Selat akan

menerapkan strategi ELVES

(Excite, Listen, Visualize,

Extend and Savor) pada materi

tertentu saja.

2. Strategi pembelajaran ELVES

(Excite, Listen, Visualize,

Extend and Savor) dapat

digunakan sebagai aternatif

strategi dalam pembelajaran

berdiskusi sehingga

pembelajaran yang

berlangsung lebih

menyenangkan dan

keterampilan berdiskusi siswa

dapat ditingkatkan.

\section{DAFTAR PUSTAKA}

Bahasa Indonesia Wahana

Pengetahuan Kls VIII SMP/MTs.

Kemendikbud.

Bulatau, S.J.J. 1985.

Tehnik Diskusi

Berkelompok.

Yogyakarta: Kanisius.

Dipodjojo, Asidi S.

1984. Komunikasi Lisan.

Yogyakarta: Lukman

Fakultas Bahasa dan Seni. 2011.

Panduan Tugas Akhir. Yogyakarta:

UNY.

Hariningsih, Dwi. 2008. Membuka Jendela

Pengetahuan dengan

dan Sastra Indonesia 2.

Jakarta. Pusat

Perbukuan,
Departemen

Pendidikan

Nasional.

Hendrikus, Dori Wuwur. 1991.

Retorika Terampil

Berpidato, Berdiskusi,

Berarumentasi,

Bernegosiasi.

Yogyakarta:

Kanisius.

Madya, Suwarsih. 2011. Teori

dan Praktik Penelitian Tindakan

(Action

Research). Bandung:

Alfabeta.

Nurgiyantoro, Burhan. 2010.

Penilaian

Pembelajaran Bahasa.

Yogyakarta: BPFE.

Setyorini, Yulianti dan Wahono. 2008. Bahasa Indonesia untuk SMP

Kelas VIII.

Jakarta:

Pusat

Perbukuan,

Departeme

$\mathrm{n}$

Pendidikan

Nasional.

Sukidin, Basrowi dan Suranto.

2008. Manajemen Penelitian

Tindakan Kelas.

Surabaya: Insan

Cendekia.

Suwandi, Sarwiji dan Sutarmo.

2008. Bahasa Indonesia

Bahasa

Kebanggaanku.Jakarta

: Pusat Perbukuan,

Departemen

Pendidikan Nasional

Tarigan, Henry Guntur. 2008.

Berbicara Sebagai Suatu

Keterampilan Berbahasa.

Bandung: Angkasa. 
Tim Redaksi, Pusat Bahasa. 2008.

Kamus Besar Bahasa Indonesia

Pusat Bahasa..

Jakarta: PT Gramedia.

Wirajaya, Asep Yudha; dan

Sudarmawarti 2008.

Berbahasa dan

Bersastra Indonesia.

Jakarta: Pusat

Perbukuan

Departemen

Pendidikan

Nasional.

Yudha Wirajaya, Asep dan

Sudarmawarti, 2008.

Berbahasa dan

Bersastra Indonesia

untuk SMP/ MTs

Kelas VIII. Jakarta:

Pusat Perbukuan,

Departemen

Pendidikan

Nasional. 